\title{
Article \\ Contribution to the Evaluation of Physicochemical Properties, Total Phenolic Content, Antioxidant Potential, and Antimicrobial Activity of Vinegar Commercialized in Morocco
}

\author{
Mohammed Kara ${ }^{1, *(D)}$, Amine Assouguem ${ }^{2} \mathbb{D}$, Mohamed El Fadili ${ }^{3} \mathbb{D}$, Safaâ Benmessaoud ${ }^{1}$,

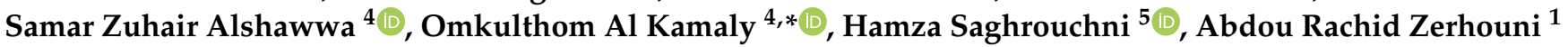 \\ and Jamila Bahhou ${ }^{1}$
}

check for

updates

Citation: Kara, M.; Assouguem, A.; Fadili, M.E.; Benmessaoud, S.; Alshawwa, S.Z.; Kamaly, O.A.; Saghrouchni, H.; Zerhouni, A.R.; Bahhou, J. Contribution to the Evaluation of Physicochemical Properties, Total Phenolic Content, Antioxidant Potential, and Antimicrobial Activity of Vinegar Commercialized in Morocco.

Molecules 2022, 27, 770 .

https://doi.org/10.3390/

molecules 27030770

Academic Editors: Alice Martins and Joaquina Pinheiro

Received: 21 December 2021

Accepted: 21 January 2022

Published: 25 January 2022

Publisher's Note: MDPI stays neutral with regard to jurisdictional claims in published maps and institutional affiliations.

Copyright: (C) 2022 by the authors. Licensee MDPI, Basel, Switzerland. This article is an open access article distributed under the terms and conditions of the Creative Commons Attribution (CC BY) license (https:// creativecommons.org/licenses/by/ $4.0 /)$.
1 Laboratory of Biotechnology, Conservation and Valorisation of Natural Resources (LBCVNR), Faculty of Sciences Dhar El Mehraz, Sidi Mohamed Ben Abdallah University, Fez 30000, Morocco; safaa.benmessaoud@usmba.ac.ma (S.B.); abdourachid.zerhouni@usmba.ac.ma (A.R.Z.); jamila.bahhou@usmba.ac.ma (J.B.)

2 Laboratory of Functional Ecology and Environment, Faculty of Sciences and Technology, Sidi Mohamed Ben Abdellah University, Fez 30000, Morocco; assougam@gmail.com

3 Laboratory of Engineering Materials Modeling and Environmental, Faculty of Sciences Dhar El Mahraz, Sidi Mohamed Ben Abdellah University, Fez 30000, Morocco; mohamed.elfadili@usmba.ac.ma

4 Department of Pharmaceutical Sciences, College of Pharmacy, Princess Nourah bint Abdulrahman University, P.O. Box 84428, Riyadh 11671, Saudi Arabia; SZAlshawwa@pnu.edu.sa

5 Department of Biotechnology, Institute of Natural and Applied Sciences, Çukurova University, Adana 01250, Turkey; hsaghrouchni@student.cu.edu.tr

* Correspondence: mohammed.kara@usmba.ac.ma (M.K.); omalkmali@pnu.edu.sa (O.A.K.)

\begin{abstract}
Vinegar is a natural product widely used in food and traditional medicine thanks to its physicochemical properties and its richness in bioactive molecules. However, its direct use by consumers can have complications and undesirable effects. Therefore, this study contributes to investigating the physicochemical and biological properties of eleven vinegars marketed in Morocco. Determination of $\mathrm{pH}$, acetic acid, conductivity, total soluble solids and alcohol content in vinegar was carried out. The polyphenols (TP), flavonoids (TF), and condensed tannins (CT) content was determined, and their antioxidant activities were evaluated using 2,2-diphenyl-1-picryl Hydrazyl (DPPH), Ferric Reducing Antioxidant Power (FRAP) and Phosphomolybdenum Reduction Assay (TAC). Then, the antimicrobial activity was studied against four pathogenic bacteria and two fungal strains, using the disk diffusion and the microdilution method. This study showed a wide range of acetic acid values from $0.65 \pm 0.29$ to $5.15 \pm 0.20 \%$. The high value of TP, TF, and CT in our samples V10, V9, and V4 was $655.00 \pm 22.2 \mu \mathrm{gGAE} / \mathrm{mL}, 244.53 \pm 11.32 \mu \mathrm{gQE} / \mathrm{mL}$ and $84.63 \pm 1.00 \mu \mathrm{gTAE} / \mathrm{mL}$, respectively. The tested strains showed variable sensitivities to the different samples with inhibition zones ranging from $6.33 \pm 2.08$ to $34.33 \pm 0.58 \mathrm{~mm}$. The lowest minimum inhibition concentrations were recorded against Staphylococcus aureus ATCC29213 ranging from 1.95 to $7.81 \mu \mathrm{L} / \mathrm{mL}$. While Aspergillus niger ATCC16404 showed resistance against all of the analyzed samples. In general, vinegar commercialized in Morocco presents a variable range of products with variable properties. Indeed, must take into account this diversity when using it. A future study is needed to identify the phytochemical composition that will further the comprehension of this variability and contribute to its valorization.
\end{abstract}

Keywords: vinegar; polyphenols; fermented fruits; antioxidant activity; antimicrobial activity; bioactive molecules

\section{Introduction}

Around the world, the use of vinegar is becoming increasingly important. It is used in various fields of application such as the nutritional, medicinal, and pharmaceutical 
fields. Its richness in biomolecules allows it to be a product of preference. Vinegar is a condiment that can be found throughout the market [1-4]. It can be made from various fruits containing carbohydrates and is obtained by alcoholic fermentation and oxidation, leading to the formation of acetic acid. This production is performed with traditional or industrial fermentation processes [5]. In the traditional method, the raw material is fermented with spontaneous microorganisms, taking weeks or months, while the industrial method is carried out to produce a fast fermentation using a liquid of fruits submerging the bacterial starter culture $[3,6]$. The final product of vinegars produced by different methods differs in its profile. In other words, there are various factors influencing the physicochemical and phytochemical parameters of the final product of vinegar, such as the raw material, production methods, temperature, $\mathrm{pH}$ and microorganisms involved in the fermentation process [7-9]. In fact, this variability influences its pharmaceutical and medicinal effects [3].

Several research studies have reported that the effect of vinegar on the human body is related to its phytochemical composition and its concentration [4], which provides excellent biological activity. According to Ozturk et al. [6], almost all of the traditional and industrial vinegar samples showed antibacterial activity at varying levels. The vinegar was shown to be effective as an antimicrobial agent against several foodborne agents and pathogenic strains such as Klebsiella pneumoniae, which causes community-onset infections and Escherichia coli, Bacillus cereus, Salmonella typhi, Pseudomonas aeruginosa and Staphylococcus aureus responsible for diarrhea [10-14]. The antifungal activity of vinegar was tested against various fungal strains of Aspergillus, Fusarium, and Candida [15,16]. Indeed, the acetic acid content in vinegar confers it an activity which can be used for the treatment of various infections even at low concentrations [3,17]. In addition, vinegar was used recently in certain dietary behaviors to prevent non-severe and severe acute respiratory syndrome (SARS) caused by a coronavirus (SARS-CoV) or as an effective disinfecting agent to stop its transmission. Several studies reported that acetic acid content was responsible for this antivirus effect by its application alone or combined (at $0.34 \%$ concentration) with hydroxychloroquine [18-20]. The polyphenol content in vinegar is known for its considerable biological effect on the human body as an antioxidant agent involved in several biological processes $[4,21]$. The major phenolic compounds that can be found in vinegar are phenolic acids, flavonoids, tannins, anthocyanins, and stilbenoids [22-24]. In addition, vinegar is rich in mineral and volatile compounds [6]. These properties of vinegar mean it experiences remarkably widespread consumption in the whole world. This leads us to pay particular attention to the quality of the vinegar produced and to question the products available on the market. Therefore, the present study aimed to investigate the variation of physicochemical parameters in different kinds of vinegar commercialized in Morocco. Meanwhile, we characterized the total phenolic content, total flavonoid, and condensed tannins and their antioxidant and antimicrobial activities. This study is considered the first to be conducted in Morocco and would be helpful to characterize different kinds of Moroccan vinegar in order of its valorization in the future.

\section{Results and Discussion}

\subsection{Physicochemical Analysis}

The results of the physicochemical analysis of vinegar commercialized in Morocco are shown in Table 1 . The $\mathrm{pH}$ measurement showed variable values ranging between $2.37 \pm 0.09$ and $4.47 \pm 0.08$ for $\mathrm{V} 4$ and $\mathrm{V} 8$, respectively. In general, $\mathrm{pH}$ values of traditionally produced vinegar were higher than the industrially produced ones, and many other samples. These results are in line with previous studies established by [25-27]. The TSS values were between $1.03 \pm 0.18{ }^{\circ}$ Brix and $8.67 \pm 0.12{ }^{\circ}$ Brix. The V9 and V8 values represent higher conductivity values in the order of $6.19 \pm 0.29$ and $5.67 \pm 0.50 \mu \mathrm{S} / \mathrm{cm}$, respectively. Compared to the other research, these values are similar to those reported by $[14,28-30]$. The acetic acid contents in vinegar V2 (5.15\%), V9 $(4.98 \%), \mathrm{V} 1$ and V5 $(3.75 \%)$ are higher than those of the other samples. The alcohol content in the vinegar samples of 
this research ranged from $0.03 \pm 0.02$ to $1.00 \pm 0.00 \%$ for V2 and V3, respectively. Except for V2, these values were not in conformity with the standard which must be less than $0.1 \%$ for residual alcohol content and more than $5 \%$ for the degree of acidity [31].

\subsection{Determination of Total Phenolic, Total Flavonoids, and Condensed Tannins Content}

Polyphenols and flavonoids are the main bioactive compounds in vinegar that can be obtained from various raw materials, which are responsible for several positive effects on health [32,33]. Table 1 summarizes the results of the phenolic compounds in the different types of vinegar studied. It was demonstrated that V10, V7, V9 are very rich in total polyphenols $(655.00 \pm 22.2,577.89 \pm 13.47$ and $521.22 \pm 12.73 \mu \mathrm{g} \mathrm{GAE} / \mathrm{mL}$, respectively) compared to the other samples. The lowest value was $6.22 \mu \mathrm{g} \mathrm{GAE} / \mathrm{mL}$, which was recorded in V6. The flavonoid content range between $18.67 \pm 4.56$ and $244.53 \pm 11.32 \mu \mathrm{g} \mathrm{QE} / \mathrm{mL}$ in all samples except V6 and V11, which do not show any traces of flavonoids. The highest concentration of Flavones and Flavonols recorded in our vinegar samples was $225.20 \pm 17.6 \mu \mathrm{g} \mathrm{QE} / \mathrm{mL}$ for $\mathrm{V} 9$, followed in descending order by V7 with $114.72 \pm 11.16 \mu \mathrm{g} \mathrm{QE} / \mathrm{mL}$, while the lowest values were $2.33 \pm 0.58 \mu \mathrm{g} \mathrm{QE} / \mathrm{mL}$ and $3.67 \pm 3.50 \mu \mathrm{g} \mathrm{QE} / \mathrm{mL}$ for $\mathrm{V} 2$ and V3, respectively. These results are in line with previous research that reported that TPC and TFC in apple vinegar are lower than in most fruit vinegar $[6,12,14,34]$. Sengun et al. reported that the TPC in grape and apple vinegar was $1025 \pm 2.83$ and $988 \pm 2.83 \mathrm{mg} \mathrm{GAE} / \mathrm{L}$, and the TFC was $221.81 \pm 3.43$ and $174.79 \pm 3.40 \mathrm{mg}$ Catechin/L, respectively [14]. Yun et al. found that TPC and TFC contained in peach were $437.6 \pm 29.8 \mathrm{mg} / \mathrm{L}$ and $30.3 \pm 2.1 \mathrm{mg} / \mathrm{L}$, respectively [35]. Moreover, the total phenolic content (TPC) and total flavonoid content (TFC) of traditional vinegar are significantly higher than those of industrial vinegars $[6,12]$. In the case of condensed tannins, the concentration varies in all the studied samples between $84.63 \pm 1.00 \mu \mathrm{g}$ TAE $/ \mathrm{mL}$ and $0.69 \pm 0.53 \mu \mathrm{g}$ TAE $/ \mathrm{mL}$. V6 record the lowest concentration, while V4 has a very high concentration compared to the other samples. According to the scientific literature, procyanidins and condensed tannins are the major substances of most apple varieties [36]. In general, the phytochemical compound in vinegar varies widely depending on the raw material used in its production [6] and on the strain of yeast and acetic acid bacteria involved [9].

\subsection{In Vitro Antioxidant Activity}

The antioxidant activity of the different types of vinegar studied in this research was evaluated using three complementary tests: DPPH, FRAP, and TAC assay. The results are shown in Figure 1. It is shown in these results (Figure 1A) that V10, V3, V2, V9, and V8 have a lower DPPH IC50 value $(6.441 \mu \mathrm{g} / \mathrm{mL}, 6.581 \mu \mathrm{g} / \mathrm{mL}, 10.508 \mu \mathrm{g} / \mathrm{mL}$, $12.852 \mu \mathrm{g} / \mathrm{mL}$, and $13.465 \mu \mathrm{g} / \mathrm{mL}$, respectively), while $50 \%$ inhibition for $\mathrm{V} 6$ and V11 was not attained. According to the results found by [35] on various fruit vinegars, the peach vinegar and the grape vinegar record a higher value of antioxidant activity using DPPH assay (94.7 $\pm 0.7 \%$ and $82.4 \pm 1.5 \%$, respectively) in comparison with apple vinegar which was between $61.2 \pm 0.4 \%$ and $72.2 \pm 1.4 \%$ [35]. In addition, Ozturk et al. reported several ranges of DPPH values, which ranged from $4.93 \%$ to $89.53 \%$ for grape vinegar, while they ranged from $0.53 \%$ to $65.12 \%$ for apple vinegar [6]. In addition, the antioxidant property of fruit vinegar, including traditional balsamic vinegar and peach vinegar, was over $90 \%$ [35]. The antioxidant power based on the FRAP assay indicated significant outcomes between different samples (Figure 1B). The IC50 values of V8, V7, and V2 were much lower $(8.369 \mu \mathrm{g} / \mathrm{mL}$ and $19.072 \mu \mathrm{g} / \mathrm{mL}$, respectively) than $\mathrm{V} 1, \mathrm{~V} 4, \mathrm{~V} 5, \mathrm{~V}$, and V10 while the highest IC50\% value was recorded in the V10 sample $(461.536 \mu \mathrm{g} / \mathrm{mL})$. According to [12], the FRAP values of apple vinegar were lower than those of grape vinegar. As shown in Figure 1C, among the tested vinegar samples, V1 and V8 were found to exhibit the highest total antioxidant capacities with the values of 134.068 and $119.903 \mu \mathrm{g}$ AAE/mL, respectively. While the lowest values were recorded in V11 (31.814 $\mu \mathrm{g}$ AAE/mL). In a related study, [35] recorded that, in peach vinegar, the IC50 was $(13.1 \pm 0.6 \mu \mathrm{g} / \mathrm{mL})$. Several studies have 
reported that the difference in antioxidant capacity is due to differing their phytochemical profiles and initial raw materials [14].

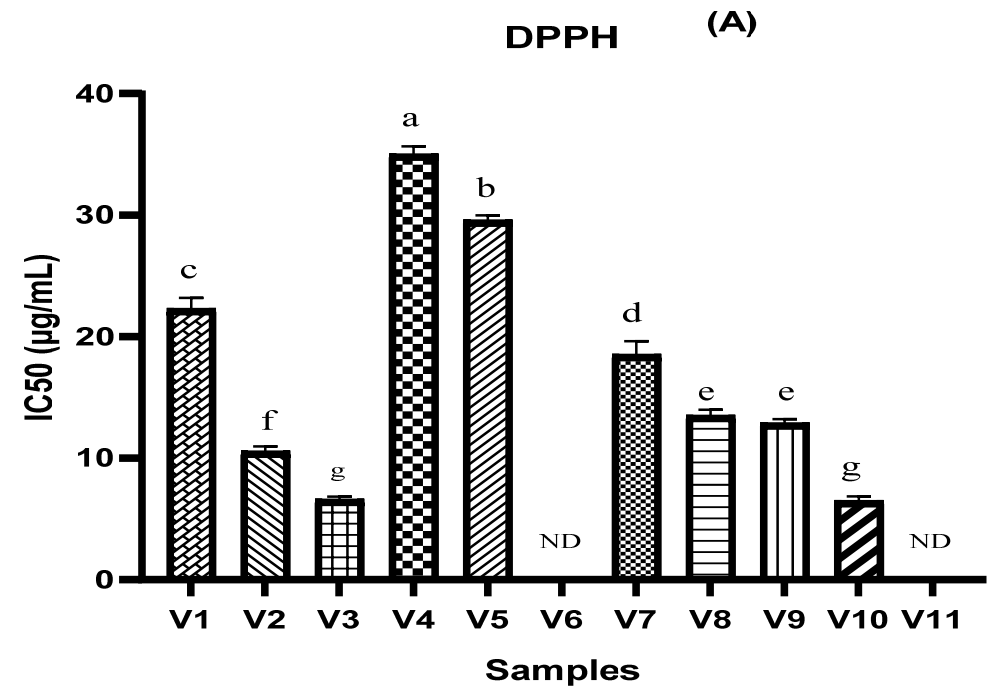

FRAP (B)

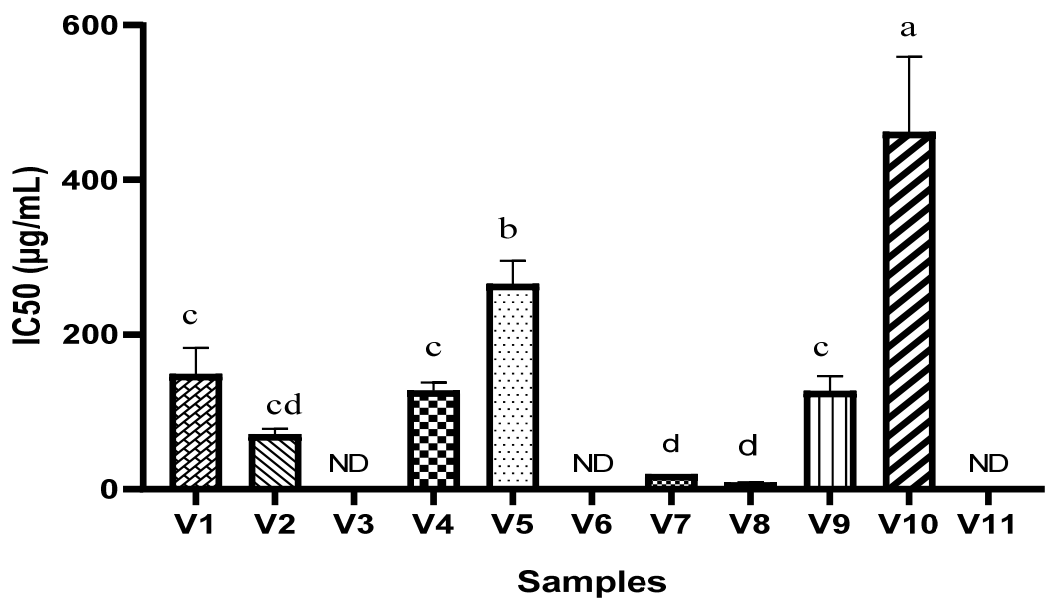

TAC (C)

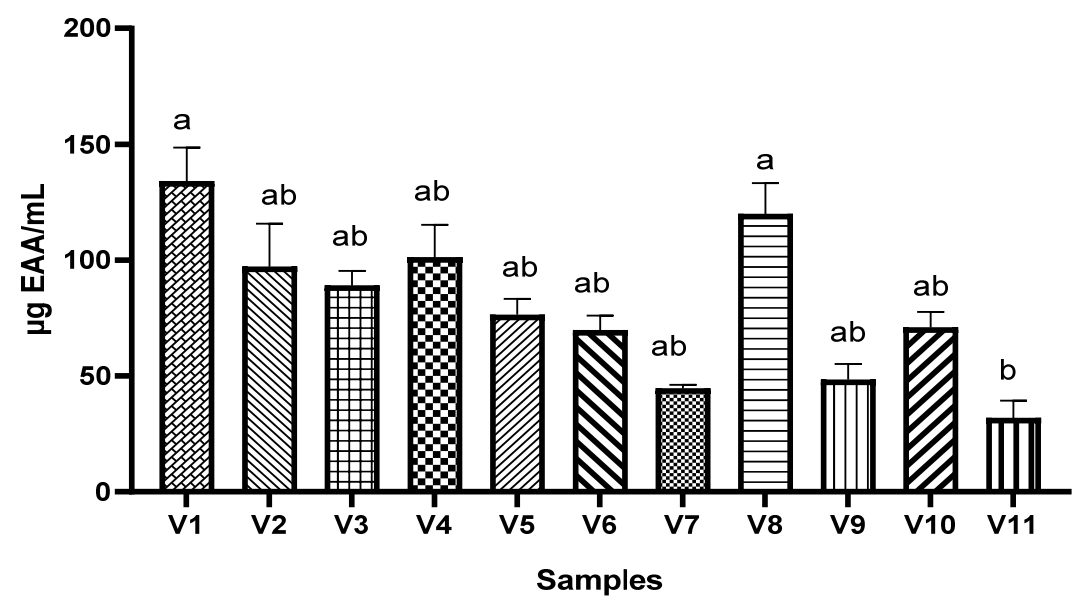

Figure 1. Antioxidant activity of different vinegar samples tested by 2,2-diphenyl-1-picryl hydroxyl radical scavenging assay (A), ferric reducing antioxidant power assay (B), and phosphomolybdenum reduction assay $(\mathbf{C})$. $\mathrm{ND}=50 \%$ inhibition not determined. Values that do not share the same letter are significantly different. 


\subsection{Antimicrobial Analysis}

\subsubsection{Disk Diffusion Assay}

The antimicrobial activities of the vinegar samples were tested against bacterial and fungal strains using the disc diffusion method, and the outcomes are shown in Table 2. The sensitivity of the bacteria to the various vinegar samples was highly variable. The highest value of inhibition was recorded against K. pneumonia (ESBL-KP) in the range of $8.67 \pm 1.15 \mathrm{~mm}$ and $32.67 \pm 2.52 \mathrm{~mm}$ for V11 and V5, respectively. The V11 and V10 revealed a higher antibacterial activity $(25.67 \pm 0.58$ and $24.67 \pm 0.58 \mathrm{~mm})$ against the E. coli ATCC strain followed by V9, V3, and V2 with DIZ of $18.67 \pm 2.31,18.33 \pm 1.53$ and $18.00 \pm 0.00 \mathrm{~mm}$, respectively., while the lowest activity was $7.33 \pm 0.58$ and $6.67 \pm 0.58 \mathrm{~mm}$ for V4 and V6, respectively. Except for sample V11, we can note that all samples have antibacterial activity against $E$. coli $\mathrm{CIP}$ ranging between the lowest value of $6.33 \pm 2.06 \mathrm{~mm}$ and the highest of $25.33 \pm 0.58 \mathrm{~mm}$ for V6 and V10, respectively. Antibacterial activity against $S$. aureus was shown to be the lowest in this study with DIZs ranging from $9.00 \pm 1.73 \mathrm{~mm}$ to $16.33 \pm 1.15 \mathrm{~mm}$ for V4 and V9, respectively. Concerning A. niger strains, we can clearly note its resistance to all the vinegar samples used in this study, while the antimicrobial activity against $C$. albicans yeast ranged between $8.00 \pm 0.00$ and $34.33 \pm 0.58 \mathrm{~mm}$ for V7 and V1, respectively. Generally, the peach, grape, and apple vinegar purchased from cooperatives and ACV obtained from the local market had a stronger antibacterial activity. Several studies showed that apple vinegar had low antimicrobial activity against almost all strains of microorganisms $[16,37,38]$. The antimicrobial activity of each vinegar sample is strongly correlated with their phytochemical compounds $[4,39]$. Indeed, the qualitative and quantitative difference of organic acids, polyphenols and primary metabolites contained in each kind of vinegar are the main factors responsible for the variation of the antimicrobial activity $[40,41]$. The presence of bioactive compounds, such as Gallic acid, Epicatechin-3-gallate, Caffeic acid, Catechins, amino acids and acetic acid, in the vinegar can inhibit the bacteria strains at low concentration such as $S$. aureus, S. mutans, E. coli O157:H7 and P. aeruginosa $[40,41]$. The previous literature showed that polyphenols contained in the apple vinegar is generally lower than that found in the other fruits' vinegar [42,43].

\subsubsection{Determination of the Minimum Inhibitory Concentration (MIC)}

The results of the antimicrobial activity of the samples obtained through the microdilution method were presented in Table 2. The Minimum Inhibitory Concentration (MIC) recorded in this study was in the range of $1.95 \mu \mathrm{L} / \mathrm{mL}$ and $500 \mu \mathrm{L} / \mathrm{mL}$. The MIC values recorded against E. coli ATCC were $1.95 \mu \mathrm{L} / \mathrm{mL}$ for (V6 and V9), $3.9 \mu \mathrm{L} / \mathrm{mL}$ for V8, and $7.81 \mu \mathrm{L} / \mathrm{mL}$ for the other samples. The lowest antimicrobial activity recorded against E. coli $\mathrm{CIP}$ was $62.5 \mu \mathrm{L} / \mathrm{mL}$ by V7 sample and the highest was $1.95 \mu \mathrm{L} / \mathrm{mL}$. The antimicrobial activity of all samples against $S$. aureus ranged between $1.95 \mu \mathrm{L} / \mathrm{mL}$ and $7.81 \mu \mathrm{L} / \mathrm{mL}$. Generally, the lowest antimicrobial activity in this study was recorded against the yeast C. albicans which falls within the range of $31.25 \mu \mathrm{L} / \mathrm{mL}$ and $500 \mu \mathrm{L} / \mathrm{mL}$ for V6 and V5, respectively, and the highest activity was against $S$. aureus with MIC of $1.95 \mu \mathrm{L} / \mathrm{mL}$. According to Yagnik et al., the MIC for C. Albicans was required at $1 / 2 \mathrm{ACV}$ and for S. aureus was $1 / 25$ dilution ACV was required, whereas for $E$. coli cultures the value was $1 / 50 \mathrm{ACV}$ dilution [16]. As reported by Sengun et al., apple vinegar had lower antimicrobial activity $(\mathrm{MIC}=12.5-25 \%, v / v)$ than that recorded in grape vinegar $(\mathrm{MIC}=3.12-6.25 \%, v / v)$ against all studied bacterial strains. In general, apple vinegar had higher inhibitory concentrations than grape vinegar [14]. 
Table 1. Physicochemical properties and bioactive compounds of different vinegar samples.

\begin{tabular}{|c|c|c|c|c|c|c|c|c|c|}
\hline Samples ID & Acetic Acid (\%) & $\mathrm{pH}$ & TSS $\left({ }^{\circ}\right.$ Brix $)$ & $\begin{array}{c}\text { Alcohol } \\
\text { Content (\%) }\end{array}$ & $\begin{array}{l}\text { Conductivity } \\
(\mu \mathrm{S} / \mathrm{cm})\end{array}$ & $\begin{array}{c}\text { TPC } \\
\mu \mathrm{gGAE} / \mathrm{mL}\end{array}$ & $\mathrm{TFC} \mu \mathrm{gQE} / \mathrm{mL}$ & $\begin{array}{l}\text { Flavones et } \\
\text { Flavonols } \\
\mu \mathrm{gQE} / \mathrm{mL}\end{array}$ & CTC $\mu \mathrm{gTAE} / \mathrm{mL}$ \\
\hline V1 & $3.75^{b} \pm 0.14$ & $3.33^{b} \pm 0.14$ & $5.30^{\mathrm{de}} \pm 0.14$ & $0.50^{\mathrm{bc}} \pm 0.10$ & $3.78^{b} \pm 0.25$ & $278.40^{\mathrm{e}} \pm 21.4$ & $131.09^{c} \pm 4.06$ & $67.18^{\mathrm{d}} \pm 8.84$ & $44.12^{\mathrm{d}} \pm 0.74$ \\
\hline V3 & $2.82^{\mathrm{c}} \pm 0.11$ & $2.70^{\text {dce }} \pm 0.11$ & $5.23^{\mathrm{e}} \pm 0.11$ & $1.00^{\mathrm{a}} \pm 0.00$ & $2.82^{\mathrm{cd}} \pm 0.07$ & $34.56^{\mathrm{gh}} \pm 5.85$ & $18.67^{\text {de }} \pm 4.56$ & $3.67^{\mathrm{e}} \pm 3.50$ & $27.21^{\mathrm{e}} \pm 1.73$ \\
\hline $\mathrm{V} 4$ & $1.90^{\mathrm{d}} \pm 0.09$ & $2.37^{\mathrm{e}} \pm 0.09$ & $5.47^{\mathrm{de}} \pm 0.09$ & $0.93^{a} \pm 0.09$ & $2.92^{\mathrm{cd}} \pm 0.45$ & $299.00^{\mathrm{e}} \pm 5.00$ & $43.349^{\mathrm{d}} \pm 1.550$ & $9.810^{\mathrm{e}} \pm 4.72$ & $84.63^{\mathrm{a}} \pm 1.00$ \\
\hline V5 & $3.75^{b} \pm 0.15$ & $2.77^{\mathrm{cd}} \pm 0.15$ & $7.87^{b} \pm 0.15$ & $0.50^{b c} \pm 0.15$ & $3.05^{b c d} \pm 0.08$ & $117.33^{\mathrm{f}} \pm 8.33$ & $37.49^{\mathrm{d}} \pm 12.81$ & $15.25^{\mathrm{e}} \pm 4.09$ & $55.68^{b} \pm 0.34$ \\
\hline V6 & $1.02^{\mathrm{e}} \pm 0.18$ & $2.63^{\text {de }} \pm 0.18$ & $1.03^{\mathrm{f}} \pm 0.18$ & $0.50^{b c} \pm 0.18$ & ND & $6.22^{\mathrm{h}} \pm 4.81$ & ND & ND & $0.69^{f} \pm 0.53$ \\
\hline V8 & $2.15^{\mathrm{d}} \pm 0.08$ & $4.47^{\mathrm{a}} \pm 0.08$ & $7.23^{b c} \pm 0.08$ & $0.90^{\mathrm{a}} \pm 0.08$ & $5.67^{a} \pm 0.50$ & $395.10^{d} \pm 29.6$ & $194.37^{b} \pm 16.78$ & $89.81^{\mathrm{c}} \pm 2.65$ & $45.72^{\mathrm{cd}} \pm 1.36$ \\
\hline V9 & $4.96^{\mathrm{a}} \pm 0.50$ & $2.70^{\text {cde }} \pm 0.20$ & $7.07^{\mathrm{c}} \pm 0.20$ & $0.50^{b c} \pm 0.20$ & $6.19^{a} \pm 0.29$ & $521.22^{c} \pm 12.73$ & $244.53^{a} \pm 11.32$ & $225.20^{\mathrm{a}} \pm 17.6$ & $82.18^{c} \pm 1.49$ \\
\hline V10 & $1.80^{\mathrm{d}} \pm 1.00$ & $2.57^{\text {de }} \pm 0.30$ & $8.67^{a} \pm 0.12$ & $0.73^{\mathrm{ab}} \pm 0.58$ & $2.58^{\mathrm{d}} \pm 0.32$ & $655.00^{\mathrm{a}} \pm 22.2$ & $105.07^{b} \pm 21.33$ & $47.81^{\mathrm{d}} \pm 3.31$ & $48.80^{\mathrm{c}} \pm 1.20$ \\
\hline V11 & $0.65^{\mathrm{e}} \pm 0.29$ & $2.80^{\mathrm{cd}} \pm 0.09$ & $1.17^{\mathrm{f}} \pm 0.20$ & $0.27^{\mathrm{cd}} \pm 0.29$ & ND & $82.00 \mathrm{fg} \pm 34.67$ & ND & ND & $2.85^{f} \pm 0.86$ \\
\hline
\end{tabular}

Values in the same column with different superscripts are significantly different $(p<0.05)$. ND: not determined.

Table 2. Antimicrobial activity of the different vinegars against various pathogens.

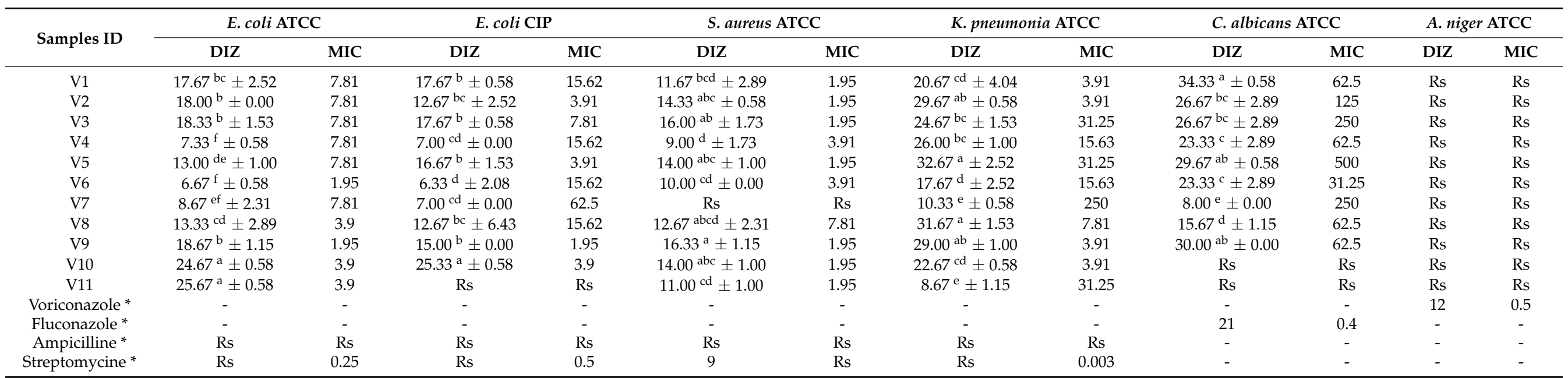

Values in the same column with different superscripts letters are significantly different $(p<0.05)$. DIZ: diameter of inhibition zone (mm); MIC: minimum inhibitory concentration $(\mu \mathrm{L} / \mathrm{mL}) ;{ }^{*}$ MIC expressed in $\mathrm{mg} / \mathrm{mL} ;$ Rs: resistant. 


\subsubsection{Principal Component Analysis of Various Studied Parameters}

Results of PCA obtained in Figure 2 show that the eigenvalues of the first four principal components represent $73.1 \%$ of the variation in the data. The first principal component shows a strong positive correlation with acetic acid, Brix, conductivity, and DIZ of K. pneumonia. The second component shows a positive correlation with DIZ of S. aureus, and a negative association with MIC of E. coli CIP and MIC of K. pneumonia. While the third component is correlated positively with flavonoids and flavonols/flavanone, and negatively with MIC of E. coli ATCC and C. albicans. The fourth one shows a negative correlation with polyphenols, and positively correlated with $\mathrm{pH}$ and MIC of $S$. aureus. In general, the variables are distributed on the different sides of the axis. However, the projection of the scoring diagram and the contribution diagram visually shows a positive contribution of physicochemical properties on the first main axis in positive correlation with V1, V2, V5, V8, and V9, while V6 and V11 were correlated negatively. The second component measures some of the antimicrobial activity of V3, V7, and V10.
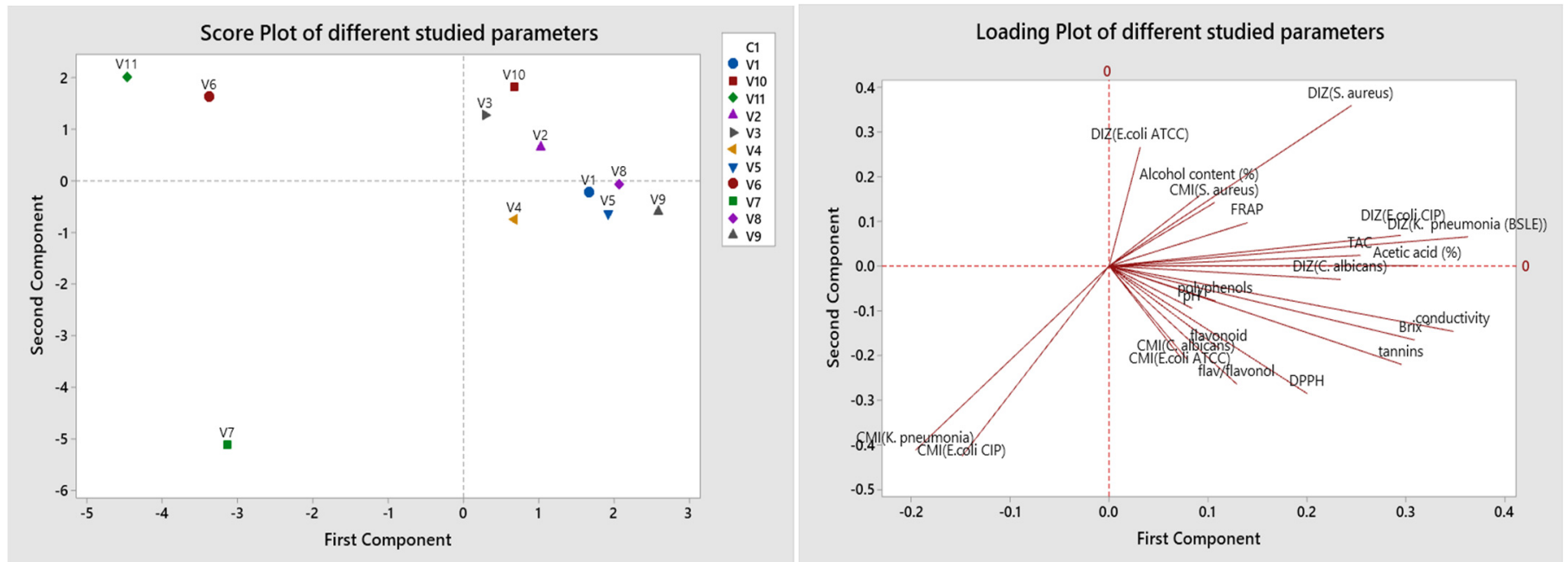

Figure 2. Principal component analysis (PCA) of the various commercialized vinegar samples using the assessed parameters.

We could conclude, based on these data, that the vinegar produced by the cooperatives and those obtained from peach, quince, and grapes have important physicochemical and biological properties. The samples obtained from the herbalists show variable characteristics. In general, the vinegar marketed in Morocco presents a variable range of products with variable properties. According to several studies, the therapeutic effects of vinegar are highly due to its bioactive compounds content [44-49]. Apple vinegar is highly rich in organic acids, phenolic acids, tannins, flavonoids, and carotenoids, which confer it with a high level of antioxidants and antibacterial properties. For a reasonable application of vinegar, its use by consumers must take into account this diversity of product characteristics.

\section{Materials and Methods}

\subsection{Raw Material}

Eleven commercial kinds of vinegar were used in this study. Ten of these were traditionally prepared from apple fruits (V1, V3, V4, V5, V6, V10, and V11), quince (V7), peach (V8), and grape (V9), and one sample was industrially prepared from apple cider (V2). The V2 and V9 samples were purchased from the local supermarket of Fez, Morocco, while V3 and V5 were obtained from vinegar-producing cooperatives located in Imouzzer Kander, Morocco, and V10 from cooperative located in Sefrou, Morocco. The other samples (V1, V4, V6, V7, V8, and V11) were purchased from Fez herbalists. All samples were centrifuged to reduce the turbidity and were stored at $4{ }^{\circ} \mathrm{C}$ for later use. 


\subsection{Physicochemical Analysis}

The percentage of acetic acid in the samples was calculated using $\mathrm{NaOH}(0.1 \mathrm{~mol} / \mathrm{L})$ [50]. The $\mathrm{pH}$ value was determined using a previously calibrated $\mathrm{pH}$ Meter SELECTA $\mathrm{pH}-2005$ (SOMESTIM, Rabat, Morocco). Conductivity $(\mu \mathrm{S} / \mathrm{cm})$ was measured by direct reading using a previously calibrated conductivity meter SELECTA CD 2005 (Lab Associates, Oudenbosch, Netherlands). A handheld refractometer with Automatic Temperature Compensation (ATC) Model ATAGO Pocket Refractometer (ATOGO, Fujian, China) was used to measure the total soluble solids (TSS) $\left({ }^{\circ}\right.$ Brix) and alcohol content $(\%)$ of the samples [51].

\subsection{Determination of Total Phenolic Content (TPC)}

The TPC of the samples was determined using the method described by [52,53]. Briefly, $0.1 \mathrm{~mL}$ of Folin-Ciocalteu reagent $(25 \%)$ is mixed with $0.1 \mathrm{~mL}$ of vinegar. The mixture is stirred vigorously and $2 \mathrm{~mL}$ of $2 \%$ sodium carbonate was added. After $30 \mathrm{~min}$ of incubation at room temperature, spectrophotometry measurement (SOMESTIM, Rabat, Morocco) was applied to the set at $760 \mathrm{~nm}$. The results are expressed as $\mu \mathrm{g} \mathrm{GAE} / \mathrm{mL}$ of vinegar sample using standard concentration curve $y=0.0006 x+0.0936, R^{2}=0.94$.

\subsection{Determination of Total Flavonoids Content (TFC)}

Total flavonoids content was determined by the methods previously described by [54]. In a test tube, $1 \mathrm{~mL}$ of vinegar and $1 \mathrm{~mL}$ of $\mathrm{AlCl}_{3}(2 \%)$ methanol solution were mixed. The absorbance of the set was measured by a UV-visible spectrophotometer UV-1600PC (VWR, Fontenay-sous-Bois, France) at $430 \mathrm{~nm}$ after $15 \mathrm{~min}$ of incubation. Ethanol and $\mathrm{AlCl}_{3}$ solution served as a control. All experiments were conducted in triplicate. A quercetin calibration curve $\left(y=0.0149 x+0.0528, R^{2}=0.99\right)$ was used to determine flavonoid concentration as micrograms of Quercetin Equivalent per $\mathrm{mL}$ of vinegar $(\mu \mathrm{g} \mathrm{QE} / \mathrm{mL})$.

\subsection{Determination of Flavones/Flavonols Content}

Flavone and Flavonol contents of the samples were determined by mixing $0.5 \mathrm{~mL}$ of vinegar with $1.5 \mathrm{~mL}$ of ethanol, $0.1 \mathrm{~mL}$ of $\mathrm{AlCl}_{3}(10 \%)$ methanol solution, $0.1 \mathrm{~mL}$ of $\left(\mathrm{CH}_{3} \mathrm{COO}, \mathrm{Na}\right)$, and $2.8 \mathrm{~mL}$ of distilled water in a test tube. The set was incubated for $30 \mathrm{~min}$ at room temperature. Absorbance of the set was measured at $415 \mathrm{~nm}$ using a UVvisible spectrophotometer UV-1600PC (VWR, Fontenay-sous-Bois, France). Our samples' concentration of flavones and flavonols was calculated using the calibration curve obtained using Quercetin as the standard $\left(y=0.0019 x+0.0447, R^{2}=0.98\right)$. All operations were repeated three times [55].

\subsection{Determination of Condensed Tannins Content (CTC)}

Calorimetric testing as described by [56] was used to determine the tannin content of the samples. Briefly, $100 \mu \mathrm{L}$ of the sample was mixed with $500 \mu \mathrm{L}$ of Folin-Ciocalteu and $1 \mathrm{~mL}$ of sodium carbonate (7.5\%). The absorbance was measured at $760 \mathrm{~nm}$ after $30 \mathrm{~min}$ of incubation. The values of condensed tannins of vinegar were expressed as micrograms of Tannic Acid Equivalent per $\mathrm{mL}$ of vinegar ( $\mu \mathrm{g} \mathrm{TAE} / \mathrm{mL}$ of vinegar) using standard concentration curve $\mathrm{y}=0.0051 \mathrm{x}+0.0289, \mathrm{R}^{2}=0.99$.

\subsection{The 2,2-Diphenyl-1-picryl Hydrazyl Radical Scavenging Activity of Vinegar}

The antioxidant activity of the samples was determined using DPPH assay as described by [57]. This method involves mixing $100 \mu \mathrm{L}$ of each methanol solution of the tested vinegar samples with $750 \mu \mathrm{L}$ DPPH in methanol $(0.004 \%)$. Its optical density is then determined at $517 \mathrm{~nm}$ after incubation at laboratory temperature for $30 \mathrm{~min}$. Methanol serves as a blank control. The following equation was used to determine the percentage inhibition of DPPH:

$$
\text { PI }(\%)=\left(1-\left(\mathrm{A}_{\mathrm{c}} / \mathrm{A}_{\mathrm{s}}\right)\right) * 100
$$


where $\mathrm{A}_{\mathrm{c}}=$ the absorbance of the control sample and $\mathrm{A}_{\mathrm{S}}=$ the absorbance of the tested sample. The half-maximal inhibitory concentration (IC50) was determined graphically.

\subsection{Ferric Reducing Antioxidant Power of Vinegar}

This test was performed using the method described by [58]; briefly, $500 \mu \mathrm{L}$ of phosphate buffer $(0.2 \mathrm{M} ; \mathrm{pH}=6.6)$ and $500 \mu \mathrm{L}$ of potassium ferricyanide $(1 \%)$ were added to $100 \mu \mathrm{L}$ of the sample at different concentrations prepared in methanol. After $20 \mathrm{~min}$ incubation at $50{ }^{\circ} \mathrm{C}$ in a water bath, $500 \mu \mathrm{L}$ of aqueous TCA $(10 \%)$ solution, $100 \mu \mathrm{L} \mathrm{FeCl}_{3}$ $(0.1 \%)$, and $0.5 \mathrm{~mL}$ of distilled water were added to the reaction medium. The absorbance of the resulting preparation was determined by the colorimetric method using UV-visiblespectrophotometer UV-1600PC (VWR, France) at $700 \mathrm{~nm}$. The tubes containing all the reagents except samples were used as a blank test. Determination of IC50 reflects the concentration of antioxidants required to obtain an absorbance of $0.5 \mathrm{~nm}$. Higher absorbance indicates the higher reducing power of the sample. Assays were carried out in triplicate [58].

\subsection{Phosphomolybdenum Reduction Assay of Vinegar}

Determination of the total antioxidant capacity (TAC) of the samples was conducted by mixing $25 \mu \mathrm{L}$ of the sample with $1 \mathrm{~mL}$ of liquid reactive solution $(0.6 \mathrm{M}$ sulfuric acid, $28 \mathrm{mM}$ sodium phosphate, and four $\mathrm{mM}$ ammonium molybdate). Then, the mixture was incubated for $90 \mathrm{~min}$ in a water bath at $95^{\circ} \mathrm{C}$. The absorbance of the incubated mixture was determined using a spectrophotometer UV-1600PC (VWR, Fontenay-sous-Bois, France) at $695 \mathrm{~nm}$ absorbance. The antioxidant capacity was expressed as micrograms of ascorbic acid equivalent per $\mathrm{mL}$ of vinegar ( $\mu \mathrm{g} \mathrm{AAE} / \mathrm{mL}$ of the sample). The equation of the standard concentration curve was $y=10.761 x+0.248, R^{2}=0.98$. Methanol was used instead of the sample as a negative control [59].

\subsection{Antimicrobial Analysis}

3.10.1. Microbial Strains and Inoculums Standardization

Six microbial strains were used in this study. Four bacterial strains: Escherichia coli ATCC 25922, Escherichia coli CIP 53126, Klebsiella pneumonia (ESBL-KP) were Gram-negative, and the one Gram-positive strain was Staphylococcus aureus ATCC 29213. Candida albicans ATCC 10231 and Aspergillus niger ATCC 16404 were used as fungal strains. All microbial strains were provided from the Microbiology Laboratory, Faculty of Medicine and Pharmacy of Fez, Morocco. The cultures were stored on Muller-Hinton agar at $4{ }^{\circ} \mathrm{C}$. The different microbial strains were standardized and inoculated following the method described in [60] for bacteria and [61] for fungal strains.

\subsubsection{Disk Diffusion Assay}

Disk diffusion assay (DD), based on the Kirby-Bauer method of [62] was used to determine the antimicrobial activity, with slight modification. The standardized suspension (1-5 $\left.\times 10^{8} \mathrm{CFU} / \mathrm{mL}\right)$ of the previously prepared isolates were inoculated onto MuellerHinton agar (MHA) for the bacteria strain. Whatman paper discs $(6 \mathrm{~mm})$ impregnated with $20 \mu \mathrm{L}$ of the vinegar samples were gently placed onto the surface of the pre-inoculated agar. The plates were left to dry for $10 \mathrm{~min}$, after which they were incubated for $24 \mathrm{~h}$ at $37^{\circ} \mathrm{C}$ [40]. After incubation, the diameters of the inhibition zones were measured in $\mathrm{mm}$. Fluconazole, Ampicilline, Streptomycine and voriconazole were used as positive controls.

\subsubsection{Determination of the Minimum Inhibitory Concentration}

The minimum inhibitory concentration (MIC) of the samples was determined using microdilution assays according to the standards of the NCCLS [63], with slight modification. Under sterile conditions, ten concentrations ranging from 500 to $3.91 \mu \mathrm{L} / \mathrm{mL}$ of each vinegar sample were prepared by successive two-fold dilutions in distilled water. Then, $50 \mu \mathrm{L}$ of the culture medium MH broth was deposited into each well of the microplate, while the 
first and the last wells were devoted to a negative control containing $100 \mu \mathrm{L}$ of the vinegar and positive growth control, respectively. Microdilutions were made by transferring $50 \mu \mathrm{L}$ by a factor of $\frac{1}{2}$ into each well. The microplate was then inoculated with $50 \mu \mathrm{L}$ of the microbial suspension. The inoculated microplate was incubated for $24 \mathrm{~h}$ at $37{ }^{\circ} \mathrm{C}$ for bacteria, and $25{ }^{\circ} \mathrm{C}$ for fungal strains. The colorimetric method based on the reagents of 2,3,5-triphenyltetrazolium chloride (TTC) was used to read the results. After $2 \mathrm{~h}$ of incubation, the MIC was determined as the lowest concentration that does not produce a pinkish coloration where there is growth due to the activity of the dehydrogenases [40].

\subsection{Statistical Analysis}

The experiments were conducted in triplicate. Multiple comparison and separation of the mean values was performed by a post hoc Tukey test at $p<0.05$. Principal component analyses (PCA) were accomplished using Minitab19.1 software to classify each kind of vinegar's in relationship with the parameters analyzed.

\section{Conclusions}

This study contributes to evaluating the physicochemical, biochemical properties, antioxidant potential, and antimicrobial activity of different kinds of vinegar commercialized in Morocco. The results showed a large diversity of vinegar products intended for direct use by the consumer. The high values of phytochemical were $655.00 \pm 22.2 \mu \mathrm{g} \mathrm{GAE} / \mathrm{mL}$ for TPC, $244.53 \pm 11.32 \mu \mathrm{g} \mathrm{QE} / \mathrm{mL}$ for TFC, and $84.63 \pm 1.00 \mu \mathrm{g} \mathrm{TAE} / \mathrm{mL}$ for CTC in V10, $\mathrm{V} 9$, and V4, respectively. The strains tested showed variable sensitivities to the different samples studied with inhibition zones ranging from $6.33 \pm 2.08 \mathrm{~mm}$ to $34.33 \pm 0.58 \mathrm{~mm}$. The lowest minimum inhibition concentrations (MIC) were recorded against Staphylococcus aureus ATCC 29213 ranging from 1.95 to $7.81 \mu \mathrm{L} / \mathrm{mL}$ of vinegar, while the filamentous fungi strain studied showed resistance against all of the analyzed samples. Therefore, the application of vinegar must take into account its phytochemical characteristics. A future study is needed to identify the phytochemical composition that will better elucidate this variability and contribute to its valorization.

Author Contributions: Conceptualization, M.K. and A.A.; methodology, M.K., M.E.F. and O.A.K.; data curation, A.A. and S.B.; writing-original draft preparation, M.K., H.S., and S.Z.A.; writingreview and editing, J.B., and A.R.Z.; supervision, J.B. All authors have read and agreed to the published version of the manuscript.

Funding: The paper is funded by Princess Nourah bint Abdulrahman University Researchers Supporting Project number (PNURSP2022R165), Princess Nourah bint Abdulrahman University, Riyadh, Saudi Arabia.

Institutional Review Board Statement: Not applicable.

Informed Consent Statement: Not applicable.

Data Availability Statement: Not applicable.

Acknowledgments: The authors extend their appreciation to Princess Nourah bint Abdulrahman University Researchers Supporting Project number (PNURSP2022R165), Princess Nourah bint Abdulrahman University, Riyadh, Saudi Arabia.

Conflicts of Interest: Data are available upon request.

Sample Availability: Samples are available from the authors upon reasonable request.

\section{References}

1. Bouderbala, H.; Kaddouri, H.; Kheroua, O.; Saidi, D. Effet Anti-Obésogène Du Vinaigre de Cidre de Pomme Chez Le Rat Soumis à Un Régime Hyperlipidique. Ann. Cardiol. D'angéiol. 2016, 65, 208-213. [CrossRef] [PubMed]

2. del Campo, G.; Berregi, I.; Santos, J.I.; Dueñas, M.; Irastorza, A. Development of Alcoholic and Malolactic Fermentations in Highly Acidic and Phenolic Apple Musts. Bioresour. Technol. 2008, 99, 2857-2863. [CrossRef] [PubMed]

3. Johnston, C.S.; Gaas, C.A. Vinegar: Medicinal Uses and Antiglycemic Effect. Med. Gen. Med. 2006, 8, 61. 
4. Petsiou, E.I.; Mitrou, P.I.; Raptis, S.A.; Dimitriadis, G.D. Effect and Mechanisms of Action of Vinegar on Glucose Metabolism, Lipid Profile, and Body Weight. Nutr. Rev. 2014, 72, 651-661. [CrossRef]

5. Junior, M.M.S.; Silva, L.O.B.; Leão, D.J.; Ferreira, S.L.C. Analytical Strategies for Determination of Cadmium in Brazilian Vinegar Samples Using ET AAS. Food Chem. 2014, 160, 209-213. [CrossRef]

6. Ozturk, I.; Caliskan, O.; Tornuk, F.; Ozcan, N.; Yalcin, H.; Baslar, M.; Sagdic, O. Antioxidant, Antimicrobial, Mineral, Volatile, Physicochemical and Microbiological Characteristics of Traditional Home-Made Turkish Vinegars. LWT Food Sci. Technol. 2015, 63, 144-151. [CrossRef]

7. Arfaoui, L. Dietary Plant Polyphenols: Effects of Food Processing on Their Content and Bioavailability. Molecules 2021, 26, 2959. [CrossRef]

8. Budak, H.N.; Guzel-Seydim, Z.B. Antioxidant Activity and Phenolic Content of Wine Vinegars Produced by Two Different Techniques. J. Sci. Food Agric. 2010, 90, 2021-2026. [CrossRef]

9. Kim, E.-J.; Cho, K.-M.; Kwon, S.J.; Seo, S.-H.; Park, S.-E.; Son, H.-S. Factors Affecting Vinegar Metabolites during Two-Stage Fermentation through Metabolomics Study. LWT 2021, 135, 110081. [CrossRef]

10. Zhang, J.; Zhou, K.; Zheng, B.; Zhao, L.; Shen, P.; Ji, J.; Wei, Z.; Li, L.; Zhou, J.; Xiao, Y. High Prevalence of ESBL-Producing Klebsiella Pneumoniae Causing Community-Onset Infections in China. Front. Microbiol. 2016, 7, 1830. [CrossRef]

11. Rasool, M.H.; Siddique, A.B.; Saqalein, M.; Asghar, M.J.; Zahoor, M.A.; Aslam, B.; Shafiq, H.B.; Nisar, M.A. Occurrence and Antibacterial Susceptibility Pattern of Bacterial Pathogens Isolated from Diarrheal Patients in Pakistan. Saudi Med. J. 2016, 37, 274-279. [CrossRef] [PubMed]

12. Bakir, S.; Devecioglu, D.; Kayacan, S.; Toydemir, G.; Karbancioglu-Guler, F.; Capanoglu, E. Investigating the Antioxidant and Antimicrobial Activities of Different Vinegars. Eur. Food Res. Technol. 2017, 243, 2083-2094. [CrossRef]

13. Al-Nabulsi, A.A.; Olaimat, A.N.; Osaili, T.M.; Shaker, R.R.; Elabedeen, N.Z.; Jaradat, Z.W.; Abushelaibi, A.; Holley, R.A. Use of Acetic and Citric Acids to Control Salmonella Typhimurium in Tahini (Sesame Paste). Food Microbiol. 2014, 42, 102-108. [CrossRef] [PubMed]

14. Sengun, I.Y.; Kilic, G.; Ozturk, B. Screening Physicochemical, Microbiological and Bioactive Properties of Fruit Vinegars Produced from Various Raw Materials. Food Sci. Biotechnol. 2020, 29, 401-408. [CrossRef] [PubMed]

15. Latgé, J.-P. Aspergillus Fumigatus and Aspergillosis. Clin. Microbiol. Rev. 1999, 12, 310-350. [CrossRef] [PubMed]

16. Yagnik, D.; Serafin, V.; Shah, A.J. Antimicrobial Activity of Apple Cider Vinegar against Escherichia Coli, Staphylococcus Aureus and Candida Albicans; Downregulating Cytokine and Microbial Protein Expression. Sci. Rep. 2018, 8, 1732. [CrossRef] [PubMed]

17. Budak, N.H.; Aykin, E.; Seydim, A.C.; Greene, A.K.; Guzel-Seydim, Z.B. Functional Properties of Vinegar. J. Food Sci. 2014, 79, R757-R764. [CrossRef]

18. Fatima, S.; Haider, N.; Alam, M.A.; Gani, M.A.; Ahmad, R.; Taha, M. Herbal Approach for the Management of C0VID-19: An Overview. Drug Metab. Pers. Ther. 2021, 36, 1-8. [CrossRef]

19. Pianta, L.; Vinciguerra, A.; Bertazzoni, G.; Morello, R.; Mangiatordi, F.; Lund, V.J.; Trimarchi, M. Acetic Acid Disinfection as a Potential Adjunctive Therapy for Non-Severe COVID-19. Eur. Arch. Oto-Rhino-Laryngol. 2020, 277, 2921-2924. [CrossRef]

20. Zhang, J.; Zhao, A.; Ke, Y.; Huo, S.; Ma, Y.; Zhang, Y.; Ren, Z.; Li, Z.; Liu, K. Dietary Behaviors in the Post-Lockdown Period and Its Effects on Dietary Diversity: The Second Stage of a Nutrition Survey in a Longitudinal Chinese Study in the COVID-19 Era. Nutrients 2020, 12, 3269. [CrossRef]

21. Gerhauser, C. Cancer Chemopreventive Potential of Apples, Apple Juice, and Apple Components. Planta Med. 2008, 74, 1608-1624. [CrossRef] [PubMed]

22. Czyżowska, A.; Wilkowska, A.; Staszczak, A.; Nowak, A. Characterization of Phytochemicals in Berry Fruit Wines Analyzed by Liquid Chromatography Coupled to Photodiode-Array Detection and Electrospray Ionization/Ion Trap Mass Spectrometry (LC-DAD-ESI-MSn) and Their Antioxidant and Antimicrobial Activity. Foods 2020, 9, 1783. [CrossRef] [PubMed]

23. Shahidi, F.; Ambigaipalan, P. Phenolics and Polyphenolics in Foods, Beverages and Spices: Antioxidant Activity and Health Effects-A Review. J. Funct. Foods 2015, 18, 820-897. [CrossRef]

24. Kara, M.; Assouguem, A.; Zerhouni, A.R.; Bahhou, J. Phytochemical Content and Antioxidant Activity of Vinegar Prepared from Four Apple Varieties by Different Methods. TJNPR 2021, 5, 1578-1585. [CrossRef]

25. Akbas, M.; Cabaroğlu, T. An research on the determination of compositions of grape vinegars produced in Turkey and their conformity to food legislation. GIDA J. Food 2010, 35, 183-188.

26. Gerbi, V.; Zeppa, G.; Beltramo, R.; Carnacini, A.; Antonelli, A. Characterisation of White Vinegars of Different Sources with Artificial Neural Networks. J. Sci. Food Agric. 1998, 78, 417-422. [CrossRef]

27. Jang, Y.K.; Lee, M.Y.; Kim, H.Y.; Lee, S.; Yeo, S.H.; Baek, S.Y.; Lee, C.H. Comparison of Traditional and Commercial Vinegars Based on Metabolite Profiling and Antioxidant Activity. J. Microbiol. Biotechnol. 2015, 25, 217-226. [CrossRef]

28. Kim, S.-H.; Cho, H.-K.; Shin, H.-S. Physicochemical Properties and Antioxidant Activities of Commercial Vinegar Drinks in Korea. Food Sci. Biotechnol. 2012, 21, 1729-1734. [CrossRef]

29. Duan, W.; Xia, T.; Zhang, B.; Li, S.; Zhang, C.; Zhao, C.; Song, J.; Wang, M. Changes of Physicochemical, Bioactive Compounds and Antioxidant Capacity during the Brewing Process of Zhenjiang Aromatic Vinegar. Molecules 2019, 24, 3935. [CrossRef]

30. Ousaaid, D.; Imtara, H.; Laaroussi, H.; Lyoussi, B.; Elarabi, I. An Investigation of Moroccan Vinegars: Their Physicochemical Properties and Antioxidant and Antibacterial Activities. J. Food Qual. 2021, 2021, e6618444. [CrossRef] 
31. ONSSA. Royaume du Maroc. Décret N²-10-385 Du 23 Joumada II 1432 (27 Mai 2011) Portant Réglementation de La Fabrication et Du Commerce Des Vinaigres 2011. Available online: http:/ / www.onssa.gov.ma/fr/reglementation?id=119 (accessed on 23 January 2021).

32. Fushimi, T.; Tayama, K.; Fukaya, M.; Kitakoshi, K.; Nakai, N.; Tsukamoto, Y.; Sato, Y. Acetic Acid Feeding Enhances Glycogen Repletion in Liver and Skeletal Muscle of Rats. J. Nutr. 2001, 131, 1973-1977. [CrossRef] [PubMed]

33. Ho, C.W.; Lazim, A.M.; Fazry, S.; Zaki, U.K.H.H.; Lim, S.J. Varieties, Production, Composition and Health Benefits of Vinegars: A Review. Food Chem. 2017, 221, 1621-1630. [CrossRef] [PubMed]

34. Ren, M.; Wang, X.; Tian, C.; Li, X.; Zhang, B.; Song, X.; Zhang, J. Characterization of Organic Acids and Phenolic Compounds of Cereal Vinegars and Fruit Vinegars in China. J. Food Processing Preserv. 2017, 41, e12937. [CrossRef]

35. Yun, J.-H.; Kim, Y.-J.; Koh, K.-H. Investigation into Factors Influencing Antioxidant Capacity of Vinegars. Appl. Biol. Chem. 2016, 59, 495-509. [CrossRef]

36. Guyot, S.; Le Bourvellec, C.; Marnet, N.; Drilleau, J.F. Procyanidins Are the Most Abundant Polyphenols in Dessert Apples at Maturity. LWT Food Sci. Technol. 2002, 35, 289-291. [CrossRef]

37. Medina, E.; ROMERO, C.; BRENES, M.; de CASTRO, A. Antimicrobial Activity of Olive Oil, Vinegar, and Various Beverages against Foodborne Pathogens. J. Food Prot. 2007, 70, 1194-1199. [CrossRef]

38. Hindi, D.N.K. In Vitro Antibacterial Activity of Aquatic Garlic Extract, Apple Vinegar and Apple Vinegar-Garlic Extract Combination. Am. J. Phytomed. Clin. Ther. 2013, 1, 42-51.

39. Karapinar, M.; Gönül, Ş.A. Effects of Sodium Bicarbonate, Vinegar, Acetic and Citric Acids on Growth and Survival of Yersinia Enterocolitica. Int. J. Food Microbiol. 1992, 16, 343-347. [CrossRef]

40. Kara, M.; Assouguem, A.; Kamaly, O.M.A.; Benmessaoud, S.; Imtara, H.; Mechchate, H.; Hano, C.; Zerhouni, A.R.; Bahhou, J. The Impact of Apple Variety and the Production Methods on the Antibacterial Activity of Vinegar Samples. Molecules 2021, $26,5437$. [CrossRef]

41. Quinto, E.J.; Caro, I.; Villalobos-Delgado, L.H.; Mateo, J.; De-Mateo-Silleras, B.; Redondo-Del-Río, M.P. Food Safety through Natural Antimicrobials. Antibiotics 2019, 8, 208. [CrossRef]

42. Kelebek, H.; Kadiroğlu, P.; Demircan, N.B.; Selli, S. Screening of Bioactive Components in Grape and Apple Vinegars: Antioxidant and Antimicrobial Potential. J. Inst. Brew. 2017, 123, 407-416. [CrossRef]

43. Gálvez, M.C.; Barroso, C.G.; Pérez-Bustamante, J.A. Analysis of Polyphenolic Compounds of Different Vinegar Samples. Z. Für. Lebensm. Unters. Und Forsch. 1994, 199, 29-31. [CrossRef]

44. Atik, D.; Atik, C.; Karatepe, C. The Effect of External Apple Vinegar Application on Varicosity Symptoms, Pain, and Social Appearance Anxiety: A Randomized Controlled Trial. Evid.-Based Complementary Altern. Med. 2016, 2016, e6473678. [CrossRef] [PubMed]

45. Gheflati, A.; Bashiri, R.; Ghadiri-Anari, A.; Reza, J.Z.; Kord, M.T.; Nadjarzadeh, A. The Effect of Apple Vinegar Consumption on Glycemic Indices, Blood Pressure, Oxidative Stress, and Homocysteine in Patients with Type 2 Diabetes and Dyslipidemia: A Randomized Controlled Clinical Trial. Clin. Nutr. ESPEN 2019, 33, 132-138. [CrossRef] [PubMed]

46. Hlebowicz, J.; Darwiche, G.; Björgell, O.; Almér, L.-O. Effect of Apple Cider Vinegar on Delayed Gastric Emptying in Patients with Type 1 Diabetes Mellitus: A Pilot Study. BMC Gastroenterol. 2007, 7, 46. [CrossRef] [PubMed]

47. Khezri, S.S.; Saidpour, A.; Hosseinzadeh, N.; Amiri, Z. Beneficial Effects of Apple Cider Vinegar on Weight Management, Visceral Adiposity Index and Lipid Profile in Overweight or Obese Subjects Receiving Restricted Calorie Diet: A Randomized Clinical Trial. J. Funct. Foods 2018, 43, 95-102. [CrossRef]

48. Samad, A.; Azlan, A.; Ismail, A. Therapeutic Effects of Vinegar: A Review. Curr. Opin. Food Sci. 2016, 8, 56-61. [CrossRef]

49. Vinayagam, R.; Xu, B. Antidiabetic Properties of Dietary Flavonoids: A Cellular Mechanism Review. Nutr. Metab. 2015, 12, 60. [CrossRef]

50. Nielsen, S.S. Standard Solutions and Titratable Acidity. In Food Analysis Laboratory Manual; Springer: Cham, Switzerland, 2010; pp. 95-102. [CrossRef]

51. Albornoz, C.E.H. Microbiological Analysis and Control of the Fruit Vinegar Production Process. Ph.D. Thesis, Universitat Rovira i Virgili, Catalonia, Spain, 2012. Available online: http:/ / purl.org/dc/dcmitype/Text. (accessed on 12 June 2021).

52. Singleton, V.L.; Rossi, J.A. Colorimetry of Total Phenolics with Phosphomolybdic-Phosphotungstic Acid Reagents. Am. J. Enol. Vitic. 1965, 16, 144-158.

53. Tsai, T.-H.; Tsai, T.-H.; Chien, Y.-C.; Lee, C.-W.; Tsai, P.-J. In Vitro Antimicrobial Activities against Cariogenic Streptococci and Their Antioxidant Capacities: A Comparative Study of Green Tea versus Different Herbs. Food Chem. 2008, 110, 859-864. [CrossRef]

54. Yang, J.-F.; Yang, C.-H.; Wu, C.-C.; Chuang, L.-Y. Antioxidant and Antimicrobial Activities of the Extracts from Sophora Flavescens. J. Pharmacogn. Phytochem. 2015, 3, 6 .

55. Ivan, K.; Marina, B.; Stjepan, P.; Sanda, V.-K. Quantitative Analysis of the Flavonoids in Raw Propolis From Northern Croatia. Available online: https:/ / pubmed.ncbi.nlm.nih.gov/15050046/ (accessed on 10 September 2020).

56. Smit, C.J.B.; Joslyn, M.A.; Lukton, A. Determination of Tannins and Related Polyphenols in Foods. Anal. Chem. 1955, 27, 1159-1162. [CrossRef]

57. Tepe, B.; Daferera, D.; Sokmen, A.; Sokmen, M.; Polissiou, M. Antimicrobial and Antioxidant Activities of the Essential Oil and Various Extracts of Salvia tomentosa Miller (Lamiaceae). Food Chem. 2005, 90, 333-340. [CrossRef] 
58. Shams Moattar, F.; Sariri, R.; Yaghmaee, P.; Giahi, M. Enzymatic and Non-Enzymatic Antioxidants of Calamintha Officinalis Moench Extracts. J. Appl. Biotechnol. Rep. 2016, 3, 489-494.

59. Maskovic, P.; Manojlovic, N.; Mandic, A.; Misan, A.; Milovanovic, I.; Radojkovic, M.; Cvijovic, M.; Solujic, S. Phytochemical Screening and Biological Activity of Extracts of Plant Species Halacsya sendtneri (Boiss.) Dörfl. Hem. Ind. 2012, 66, 43-51. [CrossRef]

60. CLSI. Methods for Dilution Antimicrobial Susceptibility Tests for Bacteria That Grow Aerobically; Clinical and Laboratory Standards Institute: Wayne, PA, USA, 2012.

61. CLSI. Reference Method for Broth Dilution Antifungal Susceptibility Testing of Filamentous Fungi, 2nd ed.; Clinical and Laboratory Standards Institute: Wayne, PA, USA, 2008; Volume 22, ISBN 978-1-56238-668-9.

62. Furtado, G.L.; Medeiros, A.A. Single-Disk Diffusion Testing (Kirby-Bauer) of Susceptibility of Proteus Mirabilis to Chloramphenicol: Significance of the Intermediate Category. J. Clin. Microbiol. 1980, 12, 550-553. [CrossRef]

63. Kiehlbauch, J.A.; Hannett, G.E.; Salfinger, M.; Archinal, W.; Monserrat, C.; Carlyn, C. Use of the National Committee for Clinical Laboratory Standards Guidelines for Disk Diffusion Susceptibility Testing in New York State Laboratories. J. Clin. Microbiol. 2000, 38, 3341-3348. [CrossRef] 